\title{
ATG16L1 Single Nucleotide Polymorphism Confers High Cardiac Artery Disease Risk in H. Pylori Chronic Gastritis Patients
}

\author{
SAMIA TAHER ALI, M.D.* and HATEM RABIE, M.D.** \\ The Departments of Internal Medicine*, Faculty of Medicine for Girls, Al-Azhar University and Clinical Pathology**, \\ National Liver Institute, Menoufia University
}

\begin{abstract}
Background: Chronic Helicobacter pylori (HP) gastritis affects two-thirds of the world's population and is one of the most common chronic inflammatory disorders of humans, the infection clearly results in chronic mucosal inflammation in the stomach and duodenum which in turn might lead to abnormalities in gastroduodenal motility and sensitivity and is the most frequent cause of dyspepsia and peptic disease. The increased inflammatory response related to HP gastrointestinal disease may also lead to damage in non-gastrointestinal tissues. The damage caused by HP is believed to be associated with increased inflammatory markers resulting from immune response and blood cells activation. Autophagy related gene 16 like 1 single nucleotide polymorphism (ATG16L1 SNP) may be associated with impaired autophagy which predisposes to HP persistence and chronicity. Chronic infection is a suspected risk factor for cardiac artery disease.
\end{abstract}

Aim of Study: The aim of this study is to assess the association between (ATG16L1) SNP and coronary artery disease, pro-inflammatory and atherogenic risk factors in HP patients.

Patients and Methods: This study was carried out on 80 patients suffering from dyspepsia and reflux symptoms. According to the urea breath test results, patients were divided into two groups: group I (45 positive H. pylori) patients and group II (35 negative H. pylori) patients as control group. All patients were subjected to full medical history taking, clinical examination and laboratory investigations included urea breath testing for $\mathrm{H}$. pylori infection, complete blood count (CBC), (ATG16L1) SNP, pro-inflammatory HDL assay and high sensitivity CRP (hs-CRP) assay.

Results: $\mathrm{H}$. pylori gastritis patients with $\mathrm{AG}+\mathrm{GG}$ genotypes had statistically higher levels of hs-CRP, N/L, P/L, pro-oxidant HDL-c index when compared to $\mathrm{H}$. pylori gastritis patients with AA genotype and both patient groups had higher levels of these parameters when compared to healthy control subjects

Conclusion: The ATG16L1 SNP impairs autophagy and has a role in persistence of $\mathrm{H}$. pylori intracellular infection leading to chronic gastritis and increases the CAD proinflammatory pro-atherogenic risk factors; the mutant $\mathrm{G}$ allele is accused allele.

Correspondence to: Dr. Samia Taher Ali, The Department of Internal Medicine, Faculty of Medicine of Girls, Al-Azhar University
Key Words: Chronic gastritis - Helicobacter Pylori - 14Curea breath test - ATG16L1 SNP - Neutrophil/ lymphocyte ratio - Platelet/lymphocyte ratio.

\section{Introduction}

HELICOBACTER pylori (HP) is a gram-negative, spiral-shaped, flagellar and microaerophilic bacillus found in the gastric mucosa of more than $50 \%$ of individuals worldwide [1]. HP has been shown to be a predisposition for chronic gastritis, gastric atrophy and gastric ulcers, as well as certain gastric cancers [2].

Autophagy is a natural cell process that allows the cell to get rid of disorganized or aged organelles [3], to combat intracellular pathogens [4] and to withstand starving conditions [5]. Genetic analysis showed that single nucleotide polymorphisms (SNPs) in autophagy pathway can affect the efficiency of autophagy including impairment of intracellular pathogen killing. One of these SNPs is the polymorphism in autophagy related gene 16 like 1 (ATG16L1) which is associated with higher risk for colonization and chronicity of intracellular infections like H. pylori [6] with subsequent increase in T-cell activation that leads to an increase in the secretion of cytokines such as interleukin-1, interleukin-6, interleukin-8 and tumor necrosis factor alpha (TNF-a) with increased C-reactive protein (CRP) levels [7].

The increased inflammatory response related to HP gastrointestinal disease may also lead to damage in non-gastrointestinal tissues [8]. The relationship between HP and vascular disorders has been confirmed in many studies [9]. The damage caused by HP on tissues is believed to be resulting from immune response and platelet activation $[10,11]$. The impaired chronic infection is a suspect- 
ed risk for coronary heart disease through establishment of a chronic inflammatory state [12] .

The aim of this study is to assess the association between (ATG 16L 1) SNP and coronary artery disease pro-inflammatory and atherogenic risk factors in $\mathrm{H}$. pylori patients.

\section{Patients and Methods}

The study was carried out on 45 patients. They were 26 females $(57.8 \%)$ and 19 males (42.2\%) aged between 25-60 years with a mean \pm SD of $41.4 \pm 7.97$ years. They were suffering from dyspepsia and reflux symptoms. The patients were recruited from the outpatient clinic and the inpatient units of the internal medicine department, Al-Azhar University Hospital, Cairo, Egypt in the period between September 2017 to June 2018. All patients provided their informed consent before being included in the study. Also, an approval of Ethical Committee of Faculty of Medicine, Al-Azhar University was obtained.

Patients were compared to a group of age and gender matched apparently healthy control subjects who were proven to be $\mathrm{H}$. pylori negative, they were 35 subjects (24 females $(68.6 \%)$ and 11 males $(31.4 \%)$ ) aged between $22-65$ years with a mean \pm SD of $40.3 \pm 11.2$ years. The presence or absence of $\mathrm{H}$. pylori was diagnosed by $\mathrm{C}$-urea breath test for $\mathrm{H}$. pylori infection.

All patients were subjected to full medical history taking, clinical examination and laboratory investigations in which few milliliters of peripheral venous blood samples were taken from each patient and placed in two EDTA and one plain vacutainers. Laboratory investigations included urea breath testing for $\mathrm{H}$. pylori infection, complete blood count (CBC) including (hemoglobin (Hb), white blood cell (WBC) count, neutrophil count, lymphocyte count, NLR, platelet count and PLR), (ATG 16L 1) SNP, pro-inflammatory HDL assay and high sensitivity CRP (hs-CRP) assay +98/iop4.

Helicobacter pylori infection was diagnosed using the urea breath test testing (UBT) that is based upon the hydrolysis of urea by $\mathrm{H}$. pylori to produce $\mathrm{CP}_{4}$ and ammonia using the nonradioactive ${ }^{{ }^{4} \mathrm{C}}$ test after an overnight fasting and at least two months without antibiotics, proton pump inhibitors (PPIs), histamine $\mathrm{H} 2$ receptor antagonists or NSAIDs therapy. (Helicap) capsules were swallowed with $25 \mathrm{ml}$ of water. Breath samples were collected with a special dry cartridge system (Heliprobe Breath Card). At 10 minutes, the
Heliprobe Breath Card was inserted into a Geigermuller counter (Heliprobe analyzer: Kibion AB, Uppsala, Sweden) and activity counted for 250 seconds. Test results were specified as counts per minute (cpm) and were graded (0: $\mathrm{cpm}<25$ : not infected \& 1: cpm 25-50: equivocal and; $2: \mathrm{cpm}$ $>50$ infected).

For the (ATG 16L 1) SNP, genomic DNA was extracted EDTA treated blood sampleusing Scientific ymobead Genomic DNA kits, MINIPREP (ZYMO RESEARCH) then sequence specific amplification was applied as previously described by Ghazi, 2016 with little modifications [6] . Briefly, for each subject, two primers consisted of a common reverse primer and a different forward specific primer was utilized for amplification of each of $\mathrm{A}$ and $\mathrm{G}$ alleles (primers supplied from Thermo Fisher Scientific, 168 Third Avenue Waltham, MA USA). The common primer was 5'AGGTGGAAAGGC TTGATATAAG'3. The specific primer for amplification of A allele was 5'CCCCAGGACAA TGTGGATA' 3 while the specific primer for amplification of $\mathrm{G}$ allele was $5^{\prime} \mathrm{CCCCAGGACAATGT-}$ GGATG'3. Cycling conditions were initial denaturation stage at $95^{\circ} \mathrm{C}$ for 10 minutes followed by 35 cycles of denaturation at $95^{\circ} \mathrm{C}$ for 30 seconds, annealing at $59^{\circ} \mathrm{C}$ for 1 minute and extension at $72^{\circ} \mathrm{C}$ for 1 minute and a final extension stage $72^{\circ} \mathrm{C}$ for 5 minutes (thermal cycler: M2000 RT Thermo scientific USA). If the corresponding allele is present, an amplified product of $201 \mathrm{bp}$ is detected by electrophoresis in $2 \%$ agarose gel.

CBC was performed by an automated hematology analyzer system (Sysmex, X T2000i, Sysmex, Japan). The total WBC count, neutrophil count, lymphocyte count, platelet count, mean platelet volume (MPV) count and hemoglobin values were recorded. Peripheral blood smears were examined for confirmation of relative differential WBC count and calculating the absolute neutrophil and lymphocyte counts, a minimum of 500 cells were counted. The neutrophil/lymphocyte ratio (NLR) was calculated by dividing the absolute neutrophil count by the absolute lymphocyte count. Similarly, Platelet/lymphocyte ratio (PLR) was calculated by dividing the platelet count by the absolute lymphocyte count.

For determination of pro-inflammatory HDLc; after elimination of other lipoproteins by precipitation of apo B-containing lipoproteins (Spinreact, Girona, Spain), the supernatant containing HDLc was separated. Pro-inflammatory HDL-c was measured as described by Navab et al., [13] with 
slight modifications. In brief, 25 testandard LDL solution containing 2.5 LOL-c and 2.5 of tested HDL were incubated in a 96-well plate for $30 \mathrm{~min}$ at $37^{\circ} \mathrm{C}$. Then, 25 2 2 -dichlorfluorescein (DCFH) (Sigma-Aldrich, Missouri, USA) with a concentration of $0.2 \mathrm{mg} / \mathrm{ml}$ in methanol were added to each well. The oxidized DCFH turns to a highly fluorescent material (emitted light $530 \mathrm{~nm}$ ). After $60 \mathrm{~min}$ of incubation at $37^{\circ} \mathrm{C}$, fluorescence intensity was measured by Thermo scientific, Multiskan FC, USA. Values for the fluorescence intensity induced by test HDL + standard LDL were divided by the basal values obtained with standard LDLs alone to obtain an index value. Index values $\geq 1$.0 indicate dysfunctional HDLs (pro-oxidant HDL), while values $<1.0$ indicates normal, antioxidant HDLs.

The hs-CRP was measured by immunoturbidimetry using the Cobas C 501, Roche, Japan.

Exclusion criteria included pregnancy, age less than 18 years, diabetes mellitus, hepatic and renal diseases, abnormal thyroid function tests, previous history of local or systemic infection, acute and chronic inflammatory diseases, hematological malignancies, using of medications for eradication of H. pylori, non-steroidal anti-inflammatory drugs (NSAIDs) or corticosteroids in the past three months.

\section{Statistical analysis:}

The data collected were tabulated and analyzed by SPSS (statistical package for social science) version 22.0 on IBM compatible computer. Descriptive statistics were expressed as mean (x) and standard deviation (SD). Analytic statistics included Chi-square test $\left(\chi^{2}\right)$ for comparison of qualitative data with numerical variables. For comparison between groups having quantitative normally distributed variables, student's t test was used in case of comparing two groups while anova (F) test was used to compare three or more groups and was followed by post hoc to study the pairwise associations. If variables are not normally distributed, Mann-Whitney (U) test was applied to compare two groups and Kruskal Wallis test was applied in case of more than two groups. $p$-value of less than 0.05 was used to indicate a statistically significant difference.

\section{Results}

No statistical difference existed between $\mathrm{H}$. pylori patients and healthy control subjects as regard to age and gender. The $\mathrm{G}$ containing genotypes and the $\mathrm{G}$ allele had a statistically signif- icant association to $\mathrm{H}$. pylori gastritis in comparison to the AA genotype and A allele respectively (Table 1).

Subjects with $\mathrm{G}$ allele containing genotypes $(\mathrm{AG}+\mathrm{GG})$ had a 2.92 folds increase in the risk of developing $\mathrm{H}$. pylori gastritis when compared to those with the AA genotype. Similarly, subjects with the A allele had a 2.6 folds increase on the risk of $\mathrm{H}$. pylori gastritis when compared to those with the A allele (Table 2).

H. pylori gastritis patients with AG+GG genotypes had statistically higher levels of hs-CRP, $\mathrm{N} / \mathrm{L}, \mathrm{P} / \mathrm{L}$, pro-oxidant HDL-c index when compared to $\mathrm{H}$. pylori gastritis patients with AA genotype and both patient groups had higher levels of these parameters when compared to healthy control subjects (Table 3 ).

Table (1): Comparison between H. pylori patients and healthy control subjects as regard to age, gender and ATG16L1 genotype and allele frequency.

\begin{tabular}{lllll}
\hline & $\begin{array}{c}\text { H. pylori } \\
\text { patients } \\
(\mathrm{n}=45)\end{array}$ & $\begin{array}{c}\text { Normal control } \\
\text { subjects } \\
(\mathrm{n}=35)\end{array}$ & Test & \\
& $41.4 \pm 7.97$ & $40.3 \pm 11.2$ & $t .0 .51$ & 0.6 \\
Age (years) & & & & \\
Gender: & 19 & 11 & $\chi^{2}$ & 0.32 \\
$\quad$ Male & 26 & 24 & 0.97 & \\
Female & & & & \\
(ATG1 6L1) & & & & \\
genotype: & 13 & 19 & $\chi^{2}$ & 0.052 \\
AA & 12 & 8 & 5.9 & \\
AG & 20 & 8 & & \\
GG & 13 & 19 & $\chi^{2}$ & 0.021 \\
AA & 32 & 16 & 5.29 & 0.3 \\
AG+GG & 20 & 8 & $\chi^{2}$ & 0.3 \\
GG & 25 & 27 & 1.03 & \\
AA+AG & & & & \\
Allele frequency: & 38 & 46 & $\chi^{2}$ & 0.003 \\
A allele & 38 & 24 & 8.7 & \\
G allele & 52 & & & \\
\hline
\end{tabular}

Table (2): Comparison between the ATG16L1 genotypes as regard to the risk of $\mathrm{H}$. pylori gastritis.

\begin{tabular}{lcclc}
\hline & $\begin{array}{c}\text { H. pylori } \\
\text { patients } \\
(\mathrm{n}=45)\end{array}$ & $\begin{array}{c}\text { Normal control } \\
\text { subjects } \\
(\mathrm{n}=35)\end{array}$ & $\begin{array}{c}\text { ODD's } \\
\text { ratio }\end{array}$ & $\begin{array}{c}p \text { - } \\
\text { value }\end{array}$ \\
\hline AA & 13 & 19 & 2.92 & 0.038 \\
AG+GG & 32 & 16 & CI: (1.15-7.38) & \\
A allele & 38 & 46 & 2.6 & 0.005 \\
G allele & 52 & 24 & CI: $1.37-5$ & \\
\hline
\end{tabular}


Table (3): Comparison between patient and control groups as regard to the pro-inflammatory markers.

\begin{tabular}{|c|c|c|c|c|c|c|}
\hline & $\begin{array}{c}\text { Patients } \\
\text { AA } \\
\text { (13) }\end{array}$ & $\begin{array}{l}\text { Patients } \\
\text { AG+GG } \\
\text { (32) }\end{array}$ & $\begin{array}{l}\text { Control } \\
\text { AA (19) }\end{array}$ & $\begin{array}{c}\text { Control } \\
\text { AG+GG } \\
\text { (16) }\end{array}$ & Test & $\begin{array}{c}p- \\
\text { value }\end{array}$ \\
\hline $\mathrm{N} / \mathrm{L}$ & $3.51+0.97$ & $4.38+2.01$ & $1.96+0.63$ & $2.11+0.37$ & $\begin{array}{l}\mathrm{K}: 30.31 \\
p<0.001\end{array}$ & $\begin{array}{l}p 1: 0.035 \\
p 2:<0.001 \\
p 3:<0.001 \\
p 4:<0.001 \\
p 5:<0.001 \\
p 6: 0.896\end{array}$ \\
\hline $\mathrm{P} / \mathrm{L}$ & $144+43$ & $186+47$ & $104+30$ & $100+33$ & $\begin{array}{l}\mathrm{F}: 24.19 \\
p:<0.001\end{array}$ & $\begin{array}{l}p 1=0.011 \\
p 2=0.035 \\
p 3=0.022 \\
p 4<0.001 \\
p 5<0.001 \\
p 6=0.99\end{array}$ \\
\hline CRP & $3.6+1.79$ & $4.86+2.22$ & $1.49+0.8$ & $1.46+0.6$ & $\begin{array}{l}\mathrm{K}: 36.09 \\
p<0.001\end{array}$ & $\begin{array}{l}p 1=0.046 \\
p 2<0.001 \\
p 3<0.001 \\
p 4<0.001 \\
p 5<0.001 \\
p 6=0.7\end{array}$ \\
\hline HDL index & $1.22+0.11$ & $1.46+0.19$ & $0.84+0.27$ & $0.76+0.19$ & $\begin{array}{l}\mathrm{F}: 59.9 \\
p:<0.001\end{array}$ & $\begin{array}{l}p 1=0.0031 \\
p 2<0.001 \\
p 3<0.001 \\
p 4<0.001 \\
p 5<0.001 \\
p 6=0.65\end{array}$ \\
\hline $\begin{array}{l}\mathrm{N} \\
\mathrm{P}\end{array}$ & $\begin{array}{l}4 \\
9\end{array}$ & $\begin{array}{l}5 \\
27\end{array}$ & $\begin{array}{l}17 \\
2\end{array}$ & $\begin{array}{l}14 \\
2\end{array}$ & $\begin{array}{l}\mathrm{x}^{2}: 37.8 \\
p:<0.001\end{array}$ & $\begin{array}{l}p 1=0.25 \\
p 2<0.001 \\
p 3<0.001 \\
p 4<0.001 \\
p 5<0.001 \\
p 6=0.72\end{array}$ \\
\hline
\end{tabular}

\section{Discussion}

Autophagy is a cell response by which the cell tries to promote its survival in face of stressful conditions, it enables the cell to decrease its energy needs and recycle its organelles to their basic elements in order to renew itself. In autophagy, cytoplasmic inclusions are sequestrated in a double membrane autophagosome which fuses with lysosomes enabling digestions of these inclusions by lysosomal enzymes [14]. These inclusions may be aged cytoplasmic organelles [15] or intracytoplasmic pathogens [16], the latter is termed xenophagy.

H. pylori is one of the common gastric infections, it is essentially an extracellular pathogen. However, it can also replicate in gastric epithelial cells [17] and subsequently is a target for autophagy. Studies have shown that the efficiency of autophagy is determined by bacterial as well as host factors. $H$. pylori virulent strains can inhibit autophagy and replicate in cytoplasmic niches [18] leading to persistence of infection and resistance to antibiotics which cannot access to the intracellular bacteria [17]. Interestingly, it was described that prolonged exposure to $\mathrm{H}$. pylori vacuolating cytotoxin (Vac A) can subvert autophagy by interference with autophagosome maturation [19] while limited exposure to the same toxin increases autophagy leading to degradation of the toxin [20]. Genetic factors also play a role in the effectiveness of autophagy against intracellular pathogens. It was described that the autophagy-related 16-like 1 gene (ATG16L1) T300A polymorphism can disrupt autophagy in $\mathrm{H}$. pylori related gastritis $[\mathbf{1 8 , 1 9 ]}$ leading to bacterial localization, persistence of infection and establishment of chronic inflammatory status [6].

Inflammation plays an important role in the pathogenesis of atherosclerosis [21]. It also weakens the atherosclerotic plaque and increases the risk 
of embolization [21]. This study aims to inspect the association of ATG16L1 SNP and chronic inflammatory and prothrombotic markers which confer a coronary artery disease (CAD) risk. The study compared hs-CRP, neutrophil/lymphocyte ratio, platelet/lymphocyte ratio and pro-inflammatory HDL-c among different ATG 16L 1 genotypes of age and gender matched $\mathrm{H}$. pylori chronic gastritis patients and normal controls.

Hs-CRP, an inflammatory marker, is a known risk predictor of CAD. Many studies proved a higher CAD risk in people having higher hs-CRP levels [22]. It was also shown the response to statins is also more pronounced when hs-CRP levels are reduced [23-27].

Neutrophil/lymphocyte ratio (NLR) and platelet/lymphocyte ratio (PLR) are novel, reliable, inexpensive, simple, safe and non-invasive laboratory markers to determine a systemic inflammation, malignances and it are being measured routinely in peripheral blood $[28,29]$. Higher platelet/lymphocyte ratio indicates a prothrombotic state [30] and a bad outcome in CAD [31]. Elevated platelet counts are associated with the development and progression of atherosclerosis [32]

The level of high-density lipoprotein (HDL-c), an apolipoprotein A1 containing lipoprotein, is usually monitored for its anti-atherosclerotic function. However, the simple measurement of HDL$\mathrm{c}$ is not reflecting its real anti-atherosclerotic ability. Various disease states change the apo-lipoprotein A1 structure reducing its anti-atherosclerotic properties and even converting it to an inflammatory pro-oxidant pro-atherosclerotic protein [33]

The current study revealed that the $G$ allele containing ATG16L1 genotypes (AG+GG) and the $\mathrm{G}$ allele are statistically more prevalent in $\mathrm{H}$. pylori patients when compared to normal control subjects. They had 2.92-and 2.6-folds risk of development of chronic $\mathrm{H}$. pylori gastritis respectively when compared to the AA genotype and the A allele respectively. According to Raju et al., [19], the GG genotype had a 1.8 folds increased risk of $\mathrm{H}$. pylori infection in comparison to the AA genotype. In his study [6], Ghazi compared between H. pylori and non-H. pylori gastritis patients. He found that the $\mathrm{G}$ allele is statistically more associated with $\mathrm{H}$. pylori related gastritis with a 1.72 folds increased risk when compared to the A allele. The ATG16L1$\mathrm{G}$ allele polymorphism is considered a loss of function substitution which impairs autophagy against intracytoplasmic invaders [34] while the presence of ATG16L 1 AA genotype helps to over- come H. pylori infection through effective autophagy which combat intracellular invasion and persistence of $\mathrm{H}$. pylori infection.

Apart from gastritis, H. pylori is accused of other local and distant diseases. H. pylori is involved in pathogenesis of mucosa associated lymphoid tissue lymphoma and gastric adenocarcinoma [35]. It was suggested that $\mathrm{H}$. pylori may have a role in the pathogenesis of liver cancer $[36,37]$, chronic urticaria [38] and other diseases. The involvement of $\mathrm{H}$. pylori infection in the pathogenesis of CAD was previously described. It was attributed to the inflammatory condition which precipitates disturbances in cytokines, fibrinogen, triglycerides, high density lipoprotein, C-reactive protein, heat shock protein, and white blood cell count creating a pro-atherosclerotic prothrombic state. The $\mathrm{H}$. pylori vacuolating cytotoxin A and cytotoxin associated gene A precipitate the formation of cholesterol deposits in arteries [39].

The present study showed that the ATG 16L 1 SNP modulates the systemic inflammatory process in $\mathrm{H}$. pylori patients. The presence of $(\mathrm{AG}+\mathrm{GG})$ genotype was linked to higher levels of inflammatory markers including hs-CRP, N/L ratio and $\mathrm{P} / \mathrm{L}$ ratio. Despite that no difference existed between the ATG 16L 1 AA and AG+GG genotype as regard to the number of patients harboring pro-inflammatory HDL-c, the level of impairment of HDL-c function as shown by HDL index was more pronounced in patients with the ATG16L1 AG+GG genotypes. In the presence of chronic inflammation, the HDL-c displays mal-functionality as it loses its LDL-c anti-oxidant ability and acquires an LDL-c pro-oxidant property which induces intracellular reactive oxygen species and promotes atherosclerosis [40].

To summarize, the ATG16L1 SNP impairs autophagy and has a role in persistence of $\mathrm{H}$. pylori intracellular infection leading to chronic gastritis and increases the CAD pro-inflammatory proatherogenic risk factors; the mutant $\mathrm{G}$ allele is accused allele.

\section{References}

1- EATON K.A., MORGAN D.R. and KRAKOWKA S.: Motility as a factor in the colonization of gnotobiotic piglets by Helicobacter pylori. J. Med. Microbiol., 37: 123-7, 1992.

2- FRYDMAN G.H., DAVIS N., BECK P.L. and FOX J.G.: Helicobacter pylori eradication in patients with immune thrombocytopenic purpura: A review and the role of biogeography. Helicobacter, 20: 239-51, 2015. 
3- KLIONSKY D.J.: "Autophagy revisited: A conversation with Christian de Duve". Autophagy, August, 4 (6): 7403. doi:10.4161/auto.6398. PMID 18567941, 2008.

4- THURSTON T.L., WANDEL M.P., VON MUHLINEN N., FOEGLEIN A. and RANDOW F.: "Galectin 8 targets damaged vesicles for autophagy to defend cells against bacterial invasion". Nature, January, 482 (7385): 414-8. doi:10.1038/nature10744. PMC 3343631. PMID 2224 6324, 2012.

5- LEVINE B. and KLIONSKY D.J.: "Development by selfdigestion: molecular mechanisms and biological functions of autophagy". Developmental Cell. April, 6 (4): 463-77. doi: 10. 1016/S 1534-5807(04)00099-1. PMID 15068787, 2004.

6- GHAZI H.F.: "Association of ATG16L1 T300A Genetic Variant with H. pylori and None H. pylori Atrophic Gastritis ". Iraqi Medical Journal, February, 2016.

7- JHA H.C., PRASAD J. and MITTAL A.: High immunoglobulin A seropositivity for combined Chlamydia pneumonia, Helicobacter pylori infection, and highsensitivity C-reactive protein in coronary artery disease patients in India can serve as atherosclerotic marker. Heart Vessels, 23: 390-396, 2008.

8- UMIT H. and UMIT E.G.: Helicobacter pylori and mean platelet volume: A relation way before immune thrombocytopenia? Eur. Rev. Med. Pharmacol. Sci., 19: 2818-23, 2015.

9- RIDKER P.M.: Inflammation, infection, and cardiovascular risk: How good is the clinical evidence? Circulation, 97: 1671-4, 1998 .

10- KALIA N., JACOB S., BROWN N.J., REED M.W., MORTON D. and BARDHAN K.D.: Studies on the gastric mucosal microcirculation. 2. Helicobacter pylori water soluble extracts induce platelet aggregation in the gastric mucosal microcirculation in viva. Gut., 41: 748-52, 1997.

11- ELIZALDE J.I., GOMEZ J., PANES J., LOZANO M., CASADEVALL M., RAMIREZ J., et al.: Platelet activation In mice and human Helicobacter pylori infection. J. Clin. Invest., 100: 996-1005, 1997.

12- LINDSBERG P.J. and GRAU A.J.: Inflammation and infections as risk factors for ischemic stroke. Stroke. Oct., 34 (10): 2518-32, 2003.

13- NAVAB M., HAMA S.Y., HOUGH G.P., SUBBANAGOUNDER G., REDDY S.T. and FOGELMAN A.M.: Cell-free assay for detecting HDL that is dysfunctional in preventing the formation of or inactivating oxidized phospholipids. J. Lipid. Res. Aug., 42 (8): 1308-17, 2001.

14- HOMMA K.S.: "List of autophagy-related proteins and 3D structures". Autophagy Database. 290. Archived from the original on 2012-08-01. Retrieved 2012-10-08, 2011.

15- CUERVO A.M., BERGAMINI E., BRUNK U.T., DRÖGE W., FFRENCH M., TERMAN A.: "Autophagy and aging: The importance of maintaining "clean" cells". Autophagy, 1 (3): 131-40. doi:10.4161/auto.1.3.2017. PMID 16874025, 2005.

16- GUTIERREZ MAXIMILIANO G., MASTER SHARON S., SINGH SUDHA B., TAYLOR GREGORY A. and COLOMBO MARIA I.: Deretic vojo "Autophagy is a defense mechanism inhibiting BCG and Mycobacterium tuberculosis survival in infected macrophages". Cell., 119
(6): 753-766. doi:10.1016/j.cell.2004.11.038. ISSN 0092 8674. PMID 15607973, 17-12-2004.

17- DEEN N.S., HUANG S.J., GONG L., KWOK T. and DEVENISH R.J.: The impact of autophagic processes on the intracellular fate of Helicobacter pylori: More tricks from an enigmatic pathogen?. Autophagy, May, 9 (5): 639-52, 2013.

18- GREENFIELD L.K. and JONES N.L.: Modulation of autophagy by Helicobacter pylori and its role in gastric carcinogenesis. Trends Microbiol, Nov., 21 (11): 602-12, 2013.

19- RAJU D., HUSSEY S., ANG M., et al.: Vacuolating cytotoxin and variants in $\operatorname{Atg} 16 \mathrm{~L} 1$ that disrupt autophagy promote Helicobacter pylori infection in humans. Gastroenterology, 142: 1160-1171, 2012.

20- TEREBIZNIK M.R., RAJU D., VÁZQUEZ C.L., TORBRICKI K., KULKARNI R., BLANKE S.R., YOSHIMORI T., COLOMBO M.I. and JONES N.L.: Effect of Helicobacter pylori's vacuolating cytotoxin on the autophagy pathway in gastric epithelial cells. Autophagy Apr., 5 (3): 370-9, 2009.

21- ROSS R: Atherosclerosis: An inflammatory disease. N. Engl. J. Med., 340: 115-26, 1999.

22- DANESH J., WHEELER J.G., HIRSCHFIELD G.M., EDA S., EIRIKSDOTTIR G., RUMLEY A., et al.: Creactive protein and other circulating markers of inflammation in the prediction of coronary heart disease. $\mathrm{N}$. Engl. J. Med., 350: 1387-97, 2004.

23- RIDKER P.M., MORROW D.A., ROSE L.M., RIFAI N., CANNON C.P. and BRAUNWALD E.: Relative efficacy of atorvastatin $80 \mathrm{mg}$ and pravastatin $40 \mathrm{mg}$ in achieving the dual goals of low-density lipoprotein cholesterol $<70 \mathrm{mg} / \mathrm{dl}$ and C-reactive protein <2mg/l: An analysis of the PROVE-IT TIMI-22 trial. J. Am. Coll. Cardiol., 45: 1644-8. [PubMed], 2005.

24- RIDKER P.M., RIFAI N., PFEFFER M.A., SACKS F. and BRAUNWALD E.: Long-term effects of pravastatin on plasma concentration of C-reactive protein. Cholesterol and Recurrent Events (CARE) Investigators. Circulation. 100: 230-5. [PubMed], 1999.

25- ALBERT M.A., DANIELSON E., RIFAI N. and RIDKER P.M.: PRINCE Investigators. Effect of statin therapy on C-reactive protein levels: The pravastatin inflammation/CRP evaluation (PRINCE): A randomized trial and cohort study. JAMA., 286: 64-70. [PubMed], 2001.

26- WIVIOTT S.D., DE LEMOS J.A., CANNON C.P., BLAZING M., MURPHY S.A., McCABE C.H., et al.: A tale of two trials: A comparison of the post-acute coronary syndrome lipid-lowering trials A to Z and PROVE ITTIMI 22. Circulation. 113: 1406-14. [PubMed], 2006.

27- JUPITER STUDY GROUP. RIDKER P.M., DANIELSON E., FONSECA F.A., GENEST J., GOTTO A.M., J.r, KASTELEIN J.J., et al.: Rosuvastatin to prevent vascular events in men and women with elevated C-reactive protein. N. Engl. J. Med., 359: 2195-207. [PubMed], 2008.

28- FENG J.F., HUANG Y. and CHEN Q.X..: Preoperative platelet lymphocyte ratio (PLR) is superior to neutrophil lymphocyte ratio (NLR) as a predictive factor in patients with esophageal squamous cell carcinoma. World J. Surg. Oncol., 12: 58, 2014. 
29- IMTIAZ F., SHAFIQUE K., MIRZA S.S., AYOOB Z., VART P. and RAO S.: Neutrophil lymphocyte ratio as a measure of systemic inflammation in prevalent chronic diseases in Asian population. Int. Arch. Med., 26; 5: 2, 2012.

30- SUNBUL M., GERIN F., DURMUS E., KIVRAK T., SARI I., TIGEN K. and CINCIN A.: Neutrophil to lymphocyte and platelet to lymphocyte ratio in patients with dipper versus non-dipper hypertension. Clin. Exp. Hypertens., 36:217-221. doi: 10.3109/10641963.2013.804547, 2014.

31- ZHOU D., WANG G., FAN Y., WAN Z. and LIU X.: Platelet to lymphocyte ratio is associated with the severity of coronary artery disease and clinical outcomes of percutaneous coronary intervention in the Chinese Han population. Exp. Ther. Med., 13 (2): 731-738, 2016.

32- THAULOW E., ERIKSSEN J., SANDVIK L., STORMORKEN H. and COHN P.F.: Blood platelet count and function are related to total and cardiovascular death in apparently healthy men. Circulation., 84: 613-617. doi: 10.1161/01.CIR.84.2.613, 1991.

33- NAMIRI-KALANTARI R., GAO F.2, CHATTOPADHYAY A., WHEELER A.A., NAVAB K.D., FARIASEISNER R. and REDDY S.T.: The dual nature of HDL: Anti-Inflammatory and pro-Inflammatory. Biofactors. May, 6: 41 (3): 153-9. doi: 10.1002/biof.1205. Epub 2015 Jun 13, 2015.

34- LASSEN K.G., KUBALLA P., CONWAY K.L., et al.: Atg16L1 T300A variant decreases selective autophagy resulting in altered cytokine signaling and decreased antibacterial defense. Proc. Natl. Acad. Sci. USA., 111: 7741-7746, 2014.

35- MAKOLA D., PEURA D.A., CROWE S.E.: Helicobacter pylori infection and related gastrointestinal diseases. J. Clin. Gastroenterol., 41: 548-558, 2007.

36- ITO K., NAKAMURA M., TODA G., NEGISHI M, TORII A. and OHNO T.: Potential role of Helicobacter pylori in hepatocarcinogenesis. Int. J. Mol. Med., 13: 221-227. [PubMed], 2004.

37- ABU AL-SOUD W., STENRAM U., LJUNGH A., TRANBERG K.G., NILSSON H.O. and WADSTRÖM T.: DNA of Helicobacter spp. and common gut bacteria in primary liver carcinoma. Dig. Liver. Dis., 40: 126-131, 2008.

38- MOGADDAM, MAJID ROSTAMI, et al.: "Relationship between Helicobacter pylori and idiopathic chronic urticaria: Effectiveness of Helicobacter pylori eradication"Postepy dermatologii i alergologii vol. 32 (1): 15-20, 2015.

39- JAMKHANDE, PRASAD G., et al.: "Helicobacter pylori and cardiovascular complications: A mechanism based review on role of Helicobacter pylori in cardiovascular diseases" Integrative medicine research vol. 5 (4): 244249, 2016.

40- SINI S. and JAYAKUMARI N.: Functionally Defective High Density Lipoprotein is Pro-Oxidant: A Deviation from Normal Atheroprotective Character, International Journal of Nutrition and Food Sciences. Vol. 2, No. 3, pp. 92-101, doi: 10.11648/j.ijnfs.20130203.11, 2013.

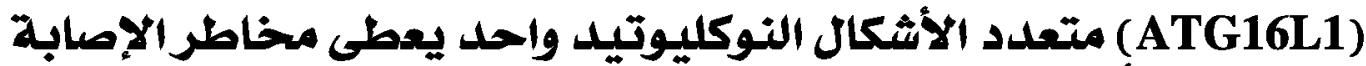

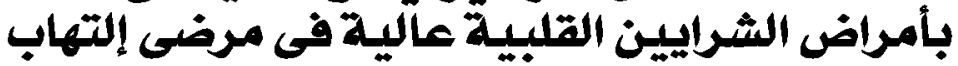 جرثومة الهعدة الهزمن اليلحن}

يؤثر إلتهاب جرثومة المعدة المزمن على ثلثي سكان العالم وهو أحد أكثر الأمراض الإلتهابية المزمنة شيوعاً بين البشر، حيث تؤدى الإصابة

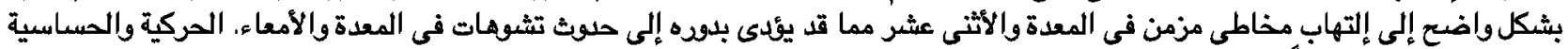

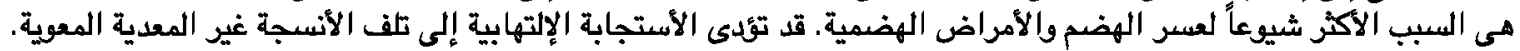

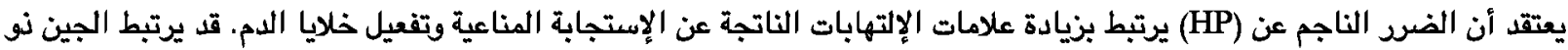

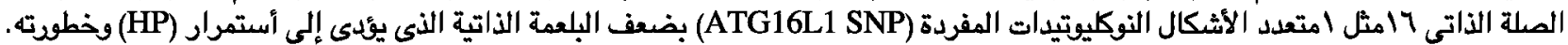

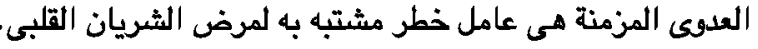

الهدف: الهدف من هذه الدراسة هو تقييم الإرتباط بين ATG16L1) SNP) ومرض شريان التاجى وعوامل الخطر المؤيدة للإلتهابات

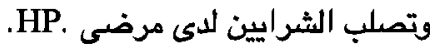

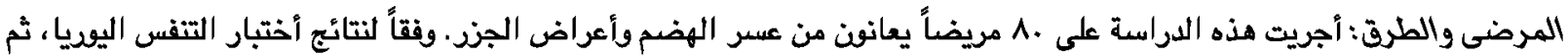

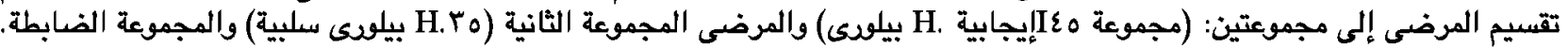

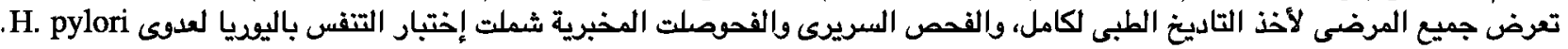

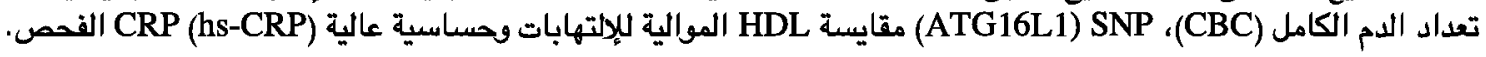

النتائج: كان لدى مرضى إلتهاب المعدة H. بيلودى مع الأنماط الوراثية AG+GG مستويات أعلى إحصائياً من

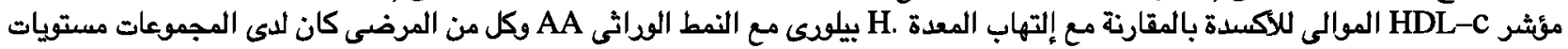

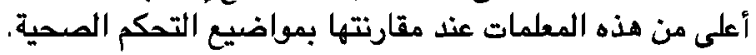

الخلاصة: أن ATG16L1 SNP يضعف الإلتهاب الذاتى ولها دود في إستمرار العلهى بين الخلايا بيلوى مما يؤدى إلى إلتهاب المعدة 